\title{
Pengaruh Keterlibatan Pengguna pada Efektivitas Penggunaan SIA dengan Kapabilitas Personal Sistem Informasi Sebagai Variabel Pemoderasi
}

\author{
Ida Bagus Baskara ${ }^{1}$ \\ I Gde Ary Wirajaya ${ }^{2}$ \\ ${ }^{1,2}$ Fakultas Ekonomi dan Bisnis Universitas Udayana (Unud), Bali, Indonesia \\ e-mail: bidabagus@gmail.com
}

\begin{abstract}
ABSTRAK
Penelitian ini bertujuan untuk mengetahui pengaruh keterlibatan pengguna pada efektivitas penggunaan sistem informasi akuntansi dan untuk mengetahui kapabilitas personal sistem informasi dalam memoderasi pengaruh keterlibatan pengguna pada efektivitas penggunaan sistem informasi akuntansi pada PT. Bank Pembangunan Daerah Bali. Jumlah responden yang digunakan dalam penelitian ini sebanyak 52 orang yang menjabat sebagai pelaksana di bagian Teknologi Informasi dan Akunting (TIA). Pengumpulan data dilakukan dengan metode survei dengan teknik pengumpulan data yang digunakan berupa kuesioner. Teknik analisis data dilakukan dengan menggunakan analisis regresi moderasi. Hasil penelitian menunjukkan bahwa keterlibatan pengguna yang ditunjang oleh kapabilitas personal sistem informasi mampu meningkatkan efektivitas penggunaan sistem informasi akuntansi pada PT. Bank Pembangunan Daerah Bali.
\end{abstract}

Kata kunci: Keterlibatan pengguna, SIA, kapabilitas personal sistem informasi.

\begin{abstract}
This study aims to determine the effect of user involvement on the effectiveness of the use of accounting information systems and to determine the personal capabilities of information systems in moderating the influence of user involvement on the effectiveness of using accounting information systems at PT. Bali Regional Development Bank. The number of respondents used in this study were 52 people who served as executors in the Information and Accounting Technology (TIA) section. Data collection is done by survey method with data collection techniques used in the form of questionnaires. Data analysis techniques were carried out using moderation regression analysis. The results of the study show that user involvement supported by the personal capabilities of information systems is able to increase the effectiveness of the use of accounting information systems at PT. Bali Regional Development Bank.

Keywords: User involvement, SIA, personal capabilities of information system.
\end{abstract}

\section{PENDAHULUAN}

Sistem informasi memiliki peran yang sangat penting di dalam bidang akuntansi, sebab pada dasarnya tujuan utama akuntansi adalah menyediakan informasi untuk para pengambil keputusan. Secara umum, semua perusahaan akan selalu memerlukan informasi dalam pengambilan keputusan. Informasi yang dibutuhkan tentunya harus akurat, yang tersedia secara realtime, dan memiliki nilai yang tepat 
dan relevan Larasdiputra (2014). Dalam rangka memberikan informasi akuntansi yang dibutuhkan oleh pihak manajer, maka dibuatlah sebuah sistem informasi yang dikenal dengan Sistem Informasi Akuntansi (SIA).

SIA adalah komponen dan elemen dari suatu organisasi yang menyediakan informasi bagi pengguna dengan pengolahan peristiwa keuangan (Zare, 2012). Penerapan SIA merupakan kualitas dari kombinasi antara hardware dan software dalam suatu sistem informasi. Hal ini ditunjukkan dengan performa dari suatu sistem yang menunjukkan seberapa baik kemampuan perangkat keras, perangkat lunak, kebijakan, dan prosedur dari suatu sistem informasi dapat menyediakan informasi kebutuhan penggunanya. SIA dapat dikatakan efektif apabila sistem mampu menghasilkan informasi yang dapat diterima dan mampu memenuhi harapan informasi secara tepat waktu (timely), akurat (accurate), dan dapat dipercaya (reliable) (Widjajanto, 2001).

Efektivitas SIA merupakan sebuah gambaran sejauh mana target dicapai dari suatu kumpulan sumber daya yang diatur untuk mengumpulkan, memproses, dan meyimpan data elektronik, kemudian mengubahnya menjadi informasi yang berguna serta menyediakan laporan formal yang dibutuhkan dengan baik secara kualitas maupun waktu Indra (2018). (Ismail, 2009) menyatakan bahwa SIA memperlancar pekerjaan karena mereka menghubungkan informasi dari bagian atas dan bawah yang membantu para pekerja di perusahaan-perusahaan untuk mencapai tujuan mereka.

Penelitian ini menggunakan teori TAM (Technology Acceptance Model) oleh Davis, Bagozzi, \& Warshaw (1989) yang diadopsi dari TRA (Theory of 
Reasoned Action) yang dikembangkan oleh Fishbe dan Ajzen pada 1980, menawarkan sebuah teori sebagai landasan untuk memperoleh pemahaman yang lebih baik mengenai perilaku pemakai dalam penerimaan dan penggunaan sistem informasi (Handayani, 2010). Model ini menunjukkan bahwa ketika terdapat suatu teknologi baru, maka penggunaan teknologi akan dihadapkan pada faktor-faktor yang memengaruhi mereka untuk menggunakan teknologi tersebut.

Sektor jasa keuangan merupakan salah satu sektor yang senantiasa menggunakan SIA sebagai alat untuk menyediakan informasi yang dapat digunakan dalam pengambilan keputusan Kharisma (2015). Salah satu perusahaan jasa keuangan yang akan selalu membutuhkan informasi yang akurat, relevan, dan tepat waktu adalah bank Larasdiputra (2014). Bank Pembangunan Daerah Bali sebagai salah satu perusahaan jasa keuangan di Provinsi Bali yang dalam kegiatannya akan selalu membutuhkan suatu informasi yang akurat, relevan, dan tepat waktu.

Saat ini, Bank Pembangunan Daerah Bali telah melakukan investasi yang besar dalam pengadaan sistem informasi, khususnya SIA, untuk meningkatkan efektivitas kinerja sistem informasi akuntansi dan kinerja karyawan. Hal ini dapat dilihat dari pengembangan teknologi pada BPD Bali yang diarahkan kepada tersedianya sistem informasi pada seluruh unit kerja. Saat ini di seluruh kantor operasional BPD Bali telah terpasang teknologi online system yang dapat berfungsi untuk mempermudah dalam transaksi keuangan. Selain itu, BPD Bali juga membantu Lembaga Perkreditan Desa (LPD) yang ada di Bali di dalam 
pengembangan sistem informasi berbasis komputer agar pelayanan kepada nasabah menjadi lebih mudah dan cepat.

Rusdi \& Megawati, (2014) dalam penelitiannya mengemukakan beberapa faktor yang berpengaruh terhadap efektivitas penggunaan sistem informasi akuntansi, diantaranya adalah keterlibatan pengguna sistem, dukungan dari manajemen puncak, ukuran organisasi, pelaithan dan pendidikan pengguna, kapabilitas personal sistem informasi, formalisasi pengembangan sistem, dan komite pengendali sistem informasi. Diantara faktor-faktor tersebut, yang berpengaruh terhadap efektivitas penggunaan sistem informasi akuntansi yaitu keterlibatan pengguna, dan kapabilitas personal sistem informasi Wilayanti (2016).

Efektifnya suatu sistem tentunya tidak terlepas dari keterlibatan pengguna sistem informasi. Keterlibatan pengguna merupakan suatu aktivitas pengguna dalam tahap pengembangan sistem informasi yang menunjukkan seberapa besar tingkat keterlibatan responden terhadap proses pengembangan sistem informasi akuntansi. (Damana, 2016) menyatakan partisipasi pemakai dalam pengembangan sistem informasi akuntansi adalah faktor efektif yang berpengaruh terhadap kinerja sistem informasi akuntansi. Menurut (Komara, 2015) pengaruh keterlibatan pemakai dalam pengembangan sistem berpengaruh positif dan signifikan terhadap kinerja SIA. (Rahmawati, 2008) berpendapat bahwa keterlibatan pemakai yang semakin sering akan meningkatkan kinerja SIA dikarenakan adanya hubungan yang positif antara keterlibatan pemakai dalam proses pengembangan sistem informasi dalam kinerja SIA. 
Menurut Harrison dan Rainer (1992), keahlian adalah suatu perkiraan atas suatu kemampuan sesorang untuk melaksanakan pekerjaan dengan sukses. Kapabilitas personal sistem informasi yang mumpuni diperlukan untuk meningkatkan kepuasan dalam penggunaan sistem informasi akuntansi. Menurut (Damana, 2016), keahlian pengguna sistem informasi pada suatu perusahaan dapat dilihat dari kemudahan pemakai dalam mengidentifikasi data, mengakses data dan menginterpretasikan data tersebut. Jika teknologi semakin canggih maka dibutuhkan keahlian yang semakin tinggi pula, hal ini sangat diperlukan untuk dapat menghasilkan informasi yang berkualitas.

Beberapa penelitian sebelumnya mengenai keterlibatan pengguna terhadap efektivitas penggunaan sistem informasi akuntansi dari (Kharisma \& Dharmadiaksa, 2015) menunjukkan bahwa keterlibatan pengguna berpengaruh signifikan terhadap efektivitas penggunaan sistem informasi akuntansi. Faktor partisipasi pengguna secara umum dari berbagai hasil riset memberikan kontribusi positif terhadap keberhasilan pengembangan sistem. Sedangkan penelitian dari (Almilia \& Briliantien, 2007) menyatakan bahwa tidak adanya hubungan yang signifikan antara partisipasi pengguna terhadap efektivitas penerapan sistem informasi akuntansi. Hasil penelitian tersebut dikarenakan pemakai sistem informasi kurang dilibatkan dalam pemakaian sistem itu sendiri, sehingga pengguna merasa tidak puas dengan sistem yang ada.

Penelitian sebelumnya dari (Almilia \& Briliantien, 2007) menyatakan bahwa tidak terdapat hubungan signifikan antara kemampuan teknik personal sistem informasi dengan kinerja sistem informasi akuntansi. Hal yang sama juga 
diungkapkan oleh (Kharisma \& Dharmadiaksa, 2015) yang menyatakan bahwa tidak terdapat hubungan signifikan antara kapabilitas sistem informasi akuntansi dengan efektivitas penggunaan sistem informasi akuntansi. Hal ini disebabkan karena dengan adanya kemampuan teknik personal sistem informasi yang terbatas akan mengakibatkan pemakaian sistem kurang, sehingga pengguna tidak merasa puas dengan sistem yang ada. Di sisi lain, Wilayanti (2016) mengungkapkan bahwa kemampuan teknik personal dan efektivitas sistem informasi akuntansi terdapat hubungan yang positif.

Technology Acceptance Model (TAM) merupakan salah satu model yang digunakan untuk menganalisis dan memahami faktor-faktor yang memengaruhi diterimanya penggunaan teknologi komputer yang diperkenalkan pertama kali oleh (Davis, 1986). Faktor-faktor tersebut yaitu persepsi kebermanfaatan dan persepsi kemudahan. TAM merupakan hasil pengembangan dari Theory of Reasoned Action (TRA), yang lebih dahulu dikembangkan oleh Fishbein dan Ajzen pada 1980.

Model TAM diadopsi dari model TRA yaitu teori tindakan yang beralasan dengan satu premis bahwa reaksi dan persepsi sesorang terhadap suatu hal, akan menemukan sikap dan perilaku orang tersebut. Reaksi dan persepsi pengguna teknologi informasi akan memengaruhi sikapnya dalam penerimaan terhadap teknologi tersebut. Salah satu faktor yang dapat memengaruhinya adalah persepsi pengguna terhadap kemanfaatan dan kemudahan penggunaan teknologi informasi sebagai suatu tindakan yang beralasan dalam konteks penggunaan teknologi, sehingga alasan seseorang dalam melihat manfaat dan kemudahan penggunaan 
teknologi informasi menjadikan tindakan/perilaku orang tersebut sebagai tolok ukur dalam penerimaan sebuah teknologi.

TAM bertujuan untuk menjelaskan dan memperkirakan penerimaan (acceptance) pengguna terhadap suatu sistem informasi. TAM menyediakan suatu basis teoritis untuk mengetahui faktor-faktor yang memengaruhi penerimaan terhadap suatu teknologi dalam suatu organisasi. TAM menjelaskan hubungan sebab akibat antara keyakinan (akan manfaat suatu sistem informasi dan kemudahan penggunaannya) dan perilaku, tujuan/keperluan, dan penggunaan aktual dari pengguna (user) suatu sistem informasi.

Persepsi kebermanfaatan dan kemudahan dalam TAM akan mengarah pada penggunaan teknologi secara nyata, sehingga secara tidak langsung pengguna akan merasa terlibat dalam implementasi sebuah teknologi. Kemudahan penggunaan berhubungan dengan keahlian teknis personal dalam menggunakan sebuah teknologi, keahlian teknis tersebut bisa diperoleh dari pelatihan dan pengalam pengguna dalam menggunakan sebuah teknologi. Bila pemakai memiliki kapabilitas personal yang mumpuni, maka penggunaan suatu sistem jelas akan lebih mudah dan suatu sistem akan menjadi efektif karena menghasilkan informasi yang berguna bagi pihak manajer perusahaan selaku pengambil keputusan.

Sistem informasi akuntansi pada dasarnya merupakan sekelompok elemen yang terintegrasi dengan maksud yang sama untuk mencapai suatu tujuan. Karena setiap sistem pengolahan transaksi memiliki siklus pengolahan transaksi, maka sistem informasi akuntansi juga dapat dikatakan sebagai integrasi dari berbagai 
siklus pengolahan transaksi. Hardware, software, brainware, prosedur, database dan jaringan komunikasi digunakan dalam sistem pengolahan transaksi atau sub informasi akuntansi.

Sistem Informasi Akuntansi (SIA) adalah alat yang dimasukkan ke dalam bidang teknologi informasi (TI), yang dirancang untuk membantu pengelolaan dan pengendalian topik yang terkait dengan bidang ekonomi dan keuangan perusahaan Grande (2011). (Novita, 2011) mengungkapkan bahwa sistem informasi akuntansi adalah suatu alat komponen sebuah organisasi yang mengumpulkan, mengklasifikasikan, mengolah, menganalisa dan mengomunikasikan informasi keuangan atau finansial dan pengambilan keputusan yang relevan bagi pihak luar perusahaan dan pihak dalam perusahaan.

Menurut Dehghanzade (2011) menyatakan bahwa sistem informasi akuntansi adalah elemen dari organisasi yang menyediakan pengguna dengan informasi peringatan dan informasi untuk pengambilan keputusan melalui pengolahan peristiwa keuangan.

Kemampuan teknik personal sistem informasi banyak memberikan dampak positif bagi perusahaan dan dunia bisnis. Penerapan suatu sistem memberikan dua dampak bagi perusahaan, yaitu keberhasilan sistem dan kegagalan sistem. Baik buruknya kinerja dari sebuah sistem informasi dapat dilihat dari kepuasan pemakai sistem informasi tersebut. Para pemakai menjadi fokus penting dalam penerapan sebuah sistem dalam perusahaan. Pemakai atau pengguna merupakan suatu hal yang tak terlepas dari penerapan teknologi, selain itu keberadaan manusia sangat berperan penting daam penerapan teknologi. 
(Ariyanto, 2007) menyatakan bahwa penggunaan sistem informasi yang tepat didukung oleh keahlian personal untuk mengoperasikan dan dapat meningkatkan kinerja perusahaan maupun kinerja individual pada perusahaan. Disamping itu, terdapat ketidakkonsistenan dalam hasil penelitian sebelumnya yang menjadi dasar peneliti memilih kapabilitas personal sistem informasi sebagai variabel pemoderasi. Peneliti ingin mengkaji kembali pengaruh kapabilitas personal sistem informasi pada efektivitas penggunaan sistem informasi akuntansi dengan harapan memperoleh hasil yang lebih akurat.

Keterlibatan pengguna dalam proses pengembangan suatu sistem diyakini dapat meningkatkan kepuasan pengguna, apabila pengguna sudah merasa puas dengan sistem yang ada, maka suatu sistem tersebut dapat dikatakan efektif. Pengguna sistem informasi yang ikut berpartisipasi dalam proses pengembangan sistem, termasuk didalamnya adalah manajer. Efektifnya suatu sistem juga tidak terlepas dari keterlibatan manajemen, (Ismail, 2009) dalam penelitiannya menyatakan bahwa partisipasi manajer dapat memengaruhi pengguna untuk mengembangkan perilaku positif yang akan meningkatkan efektivitas sistem. Hal tersebut dilihat dari penelitian yang dilakukan oleh Jin (2002) yang berpendapat bahwa keterlibatan pengguna yang semakin intens akan meningkatkan kinerja SIA dikarenakan adanya hubungan yang positif antara keterlibatan pengguna dalam proses pengembangan sistem dalam kinerja SIA. Senada dengan hal tersebut, penelitian yang dilakukan oleh Setianingsih (1998) menyebutkan bahwa keterlibatan pengguna memiliki hubungan yag positif dalam pengembangan sistem informasi. Faktor partisipasi pengguna secara umum dari berbagai hasil 
riset memberikan kontribusi positif terhadap keberhasilan pengembangan sistem. (Komara, 2015) menyatakan bahwa keterlibatan pemakai berpengaruh terhadap kinerja sistem informasi akuntansi. namun, (Almilia \& Briliantien, 2007) menyatakan bahwa tidak terdapat hubungan yang signifikan antara faktor keterlibatan pemakai dalam proses pengembangan sistem informasi dengan kinerja sistem informasi akuntansi, baik dari segi kepuasan pemakai, maupun penggunaan sistem. Berdasarkan hal tersebut, maka hipotesis yang dapat disimpulkan adalah sebagai berikut.

$\mathrm{H}_{1}$ : Keterlibatan pengguna berpengaruh pada efektivitas penggunaan sistem informasi akuntansi.

Keterlibatan pengguna dalam proses pengembangan suatu sistem diyakini dapat meningkatkan kepuasan pengguna, apabila pengguna sudah merasa puas dengan sistem yang ada maka suatu sistem tersebut dapat dikatakan sudah efektif. Pengguna sistem informasi di suatu organisasi adalah semua pengguna sistem informasi yang ikut berpartisipasi dalam proses pengembangan sistem.

Efektifnya suatu sistem juga tidak terlepas dari keterlibatan manajemen, (Ismail, 2009) dalam penelitiannya menyatakan bahwa partisipasi manajer dapat memengaruhi pengguna untuk mengembangkan perilaku positif yang akan meningkatkan efektivitas sistem. Hal tersebut dilihat dari penelitian yang dilakukan oleh (Jin, 2002) yang berpendapat bahwa keterlibatan pemakai yang semakin sering akan meningkatkan kinerja SIA dikarenakan adanya hubungan yang positif antara keterlibatan pemakai dalam proses pengembangan sistem informasi dalam kinerja SIA. Senada dengan hal tersebut, penelitian yang dilakukan oleh Setianingsih (1998) menyebutkan bahwa keterlibatan pengguna 
mempunyai hubungan yang positif dan signifikan terhadap hubungan antara keterlibatan pengguna dan kepuasan pengguna dalam pengembangan sistem informasi.

Penelitian mengenai keterlibatan pengguna, terdapat perbedaan hasil penelitian. (Jin, 2002), Setianingsih (1998) dan (Komara, 2015) menyatakan bahwa keterlibatan pemakai berpengaruh terhadap kinerja sistem informasi akuntansi. Akan tetapi, Almilia \& Briliantien (2007) menyatakan bahwa tidak terdapat hubungan yang signifikan antara faktor ketrlibatan pemakai dalam proses pengembangan sistem informasi dengan kinerja sistem informasi akuntansi, baik dari segi kepuasan pemakai atau pemakaian sistem.

Kapabilitas pengguna dalam mengoperasikan sistem informasi yang baru sangat dibutuhkan. Kapabilitas bisa diartikan sebagai kecakapan, ketangkasan, bakat, kesanggupan untuk melakukan suatu perbuatan atau pekerjaan. Pengguna sistem informasi harus memiliki kemampuan, dimana kemampuan tersebut diperoleh dari pendidikan dan pengalamannya akan meningkatkan kepuasan dalam menggunakan sistem informasi akuntansi dan akan terus menggunakannya dalam membantu menyelesaikan pekerjaannya. Menurut (Jin, 2002) dalam (Almilia \& Briliantien, 2007) berpendapat bahwa semakin tinggi kapabilitas personal sistem informasi, akan meningkatkan kinerja sistem informasi akuntansi dikarenakan adanya hubungan yang positif antara kapabilitas personal sistem informasi dengan kinerja sistem informasi akuntansi. Sejalan dengan penelitian yang dilakukan oleh (Komara, 2015) yang menemukan hubungan positif antara kemampuan teknik personal dalam sistem informasi akuntansi terhadap kinerja 
sistem informasi akuntansi. Penggunaan kapabilitas personal sistem informasi sebagai variabel pemoderasi karena ditemukan perbedaan hasil penelitian dari variabel keterlibatan pengguna. Variabel kapabilitas personal sistem informasi diharapkan memoderasi pengaruh keterlibatan pengguna pada efektivitas penggunaan sistem informasi akuntansi. Berdasarkan hal tersebut, hipotesis yang dapat disimpulkan adalah sebagai berikut.

$\mathrm{H}_{2}$ : Kapabilitas personal sistem informasi memperkuat pengaruh keterlibatan pengguna pada efektivitas penggunaan sistem informasi akuntansi.

\section{METODE PENELITIAN}

Penelitian ini dilakukan di PT. Bank Pemangunan Daerah Bali yang terletak di Jalan Raya Niti Mandala Renon, Denpasar, Bali. BPD Bali dipilih sebagai lokasi penelitian karena BPD Bali merupakan salah satu bank milik Pemerintah Daerah yang telah menggunakan sistem informasi akuntansi khususnya pada komputer. Alasan memilih lokasi ini dikarenakan saat ini Bank Pembangunan Daerah Bali telah melakukan investasi berskala besar dalam pengadaan sistem informasi, khususnya SIA untuk meningkatkan efektivitas kinerja sistem informasi akuntansi dan kinerja karyawan. Hal ini dapat dilihat dari pengembangan teknologi pada BPD Bali yang diarahkan kepada tersedianya sistem informasi pada seluruh unit kerja.

Responden dalam penelitian ini adalah karyawan PT. Bank Pembangunan Daerah Bali yang bekerja di bagian Teknologi Informasi dan Akunting yang berjumlah 52 orang. 
Penelitian ini menggunakan teknik analisis data regresi linier sederhana dan Moderated Regression Analysis (MRA). Regresi linier sederhana didasarkan pada hubungan fungsional ataupun kasual atau variabel bebas dengan satu variabel terikat. Teknik analisis data menggunakan teknik analisis regresi sederhana dengan model persamaan sebagai berikut.

$\mathrm{Y}=\alpha+\beta 1 . \mathrm{X}+\varepsilon$

Keterangan:

$\mathrm{Y} \quad=$ Variabel terikat (Efektivitas Penggunaan SIA)

$\mathrm{X} \quad=$ Variabel bebas (Keterlibatan Pengguna)

$\alpha \quad=$ Konstanta

$\beta_{1} \quad=$ Koefisien Keterlibatan Pengguna

$\varepsilon \quad=$ Kesalahan prediksi (error)

Teknik MRA digunakan untuk menguji pengaruh keterlibatan pengguna pada efektivitas penggunaan sistem infromasi akuntansi dengan kapabilitas personal sistem informasi sebagai variabel pemoderasi. Persamaan MRA sebagai berikut:

$Y=\alpha+\beta_{1} \cdot X+\beta_{2} \cdot Z+\beta_{3} \cdot X \cdot Z+\varepsilon$

Keterangan:

$\mathrm{Y} \quad=$ Variabel terikat (Efektivitas Penggunaan SIA)

$\mathrm{X} \quad=$ Variabel bebas (Keterlibatan Pengguna)

$\mathrm{Z} \quad=$ Variabel pemoderasi (Kapabilitas Personal Sistem Informasi)

$\mathrm{X} . \mathrm{Z}=$ Interaksi antara variabel bebas (Keterlibatan Pengguna) dengan variabel pemoderasi (Kapabilitas Personal Sistem Informasi)

$\alpha \quad=$ Konstanta

$\beta_{1} \quad=$ Koefisien Keterlibatan Pengguna

$\beta_{2} \quad=$ Koefisien Kapabilitas Personal Sistem Informasi

$\beta_{3}=$ Koefisien Keterlibatan Pengguna dan Kapabilitas Personal Sistem Informasi

$\varepsilon \quad=$ Kesalahan prediksi (error) 


\section{HASIL DAN PEMBAHASAN}

Karakteristik responden menggambarkan profil dari 52 responden yang berpartisipasi dalam pengisian kuesioner yang dapat dilihat pada Tabel 1.

Tabel 1.

Karakteristik Responden

\begin{tabular}{|c|c|c|c|}
\hline No. & Keterangan & $\begin{array}{l}\text { Jumlah } \\
\text { (orang) }\end{array}$ & $\begin{array}{c}\text { Persentase } \\
(\%)\end{array}$ \\
\hline \multirow[t]{4}{*}{1} & Jenis Kelamin: & & \\
\hline & Laki-laki & 33 & 63,46 \\
\hline & Perempuan & 19 & 36,54 \\
\hline & Total & 52 & 100 \\
\hline \multirow[t]{5}{*}{2} & Umur: & & \\
\hline & $20-30$ tahun & 23 & 44,23 \\
\hline & $31-40$ tahun & 14 & 26,92 \\
\hline & $>40$ tahun & 15 & 28,85 \\
\hline & Total & 52 & 100 \\
\hline \multirow[t]{6}{*}{3} & Lama Bekerja: & & \\
\hline & $<1$ tahun & 0 & 0 \\
\hline & $1-2$ tahun & 16 & 30,77 \\
\hline & $3-5$ tahun & 12 & 23,08 \\
\hline & $>5$ tahun & 24 & 46,15 \\
\hline & Total & 52 & 100 \\
\hline \multirow[t]{6}{*}{4} & Pendidikan & & \\
\hline & D3 & 2 & 03,85 \\
\hline & S1 & 42 & 80,77 \\
\hline & S2 & 8 & 15,38 \\
\hline & S3 & 0 & 0 \\
\hline & Total & 52 & 100 \\
\hline
\end{tabular}

Sumber: Data diolah, 2018

Karakteristik responden berdasarkan jenis kelamin dapat digunakan untuk mengetahui responden laki-laki dan perempuan yang bekerja di divisi TIA pada PT. Bank Pembangunan Daerah Bali. Pada Tabel 1 menunjukkan bahwa jumlah responden laki-laki sebanyak 33 orang $(63,46 \%)$ dan jumlah responden perempuan sebanyak 19 orang (36,54\%). Hal ini menunjukkan bahwa responden yang berjenis kelamin laki-laki lebih banyak dari pada perempuan.

Karakteristik responden berdasarkan umur dapat digunakan untuk mengetahui rentang umur karyawan yang bekerja di divisi TIA pada PT. Bank Pembangunan Daerah Bali. Tabel 1 menunjukkan bahwa responden yang berumur 
20 sampai dengan 30 tahun sebanyak 23 orang (44,23\%), sedangkan umur 31 sampai dengan 40 tahun sebanyak 14 orang $(26,92 \%)$, dan yang berusia lebih dari 40 tahun sebanyak 15 orang $(28,85 \%)$. Hal ini menunjukkan bahwa mayoritas responden divisi TIA di PT. Bank Pembangunan Daerah Bali diisi oleh golongan usia muda, yaitu dengan rentang usia antara 20 sampai dengan 30 tahun.

Karakteristik responden berdasarkan lama bekerja dapat digunakan untuk mengetahui pengalaman responden dalam bekerja di divisi TIA pada PT. Bank Pembangunan Daerah Bali. Tabel 1 menunjukkan bahwa tidak ada pegawai divisi TIA yang bekerja kurang dari satu tahun. Sementara itu, pegawai yang bekerja dengan rentang waktu antara 1 sampai 2 tahun sebanyak 16 orang (30,77\%). Sedangkan pegawai yang bekerja selama 3 sampai 5 tahun sebanyak 12 orang $(23,08)$. Dan pegawai divisi TIA yang bekerja selama lebih dari 5 tahun sebanyak 24 orang $(46,15 \%)$. Hal ini menunjukkan bahwa pegawai divisi TIA pada PT. Bank Pembangunan Daerah Bali mayoritas diisi oleh sumber daya yang telah berpengalaman.

Karakteristik responden berdasarkan pendidikan dapat digunakan untuk mengetahui pendidikan terakhir yang ditempuh oleh para pegawai divisi TIA pada PT. Bank Pembangunan Daerah Bali. Tabel 1 menunjukkan bahwa responden yang menempuh pendidikan pada jenjang D3 sebanyak 2 orang $(3,85 \%)$, responden yang menempuh pendidikan pada jenjang S1 sebanyak 42 orang (80,77\%). Sedangkan responden yang menempuh pendidikan pada jenjang S2 sebanyak 8 orang $(15,38 \%)$. Pada divisi TIA bank Pembangunan Daerah Bali tidak terdapat responden yang menempuh pendidikan pada jenjang S3. Hal ini 
menunjukkan bahwa pendidikan terakhir yang mendominasi adalah responden dengan jenjang pendidikan S1. Hasil uji validitas dapat dilihat pada Tabel 2 sebagai berikut.

Tabel 2.

Hasil Uji Validitas

\begin{tabular}{clccc}
\hline No. & \multicolumn{1}{c}{ Variabel } & $\begin{array}{c}\text { Item } \\
\text { Pertanyaan/ } \\
\text { Pernyataan }\end{array}$ & $\begin{array}{c}\text { Pearson } \\
\text { Correlation }\end{array}$ & Keterangan \\
\hline 1. & Keterlibatan Pengguna & X1 & 0,814 & Valid \\
& $($ X) & X2 & 0,834 & Valid \\
& & X3 & 0,642 & Valid \\
2. & Efektivitas & X4 & 0,709 & Valid \\
& Penggunaan SIA & Y1 & 0,526 & Valid \\
& (Y) & Y2 & 0,682 & Valid \\
& & Y3 & 0,678 & Valid \\
& & Y4 & 0,723 & Valid \\
& & Y5 & 0,718 & Valid \\
& & Y6 & 0,654 & Valid \\
3. & Y7 & 0,608 & Valid \\
& Kapabilitas Personal & Y8 & 0,678 & Valid \\
& Sistem Informasi & Z1 & 0,766 & Valid \\
& (Z) & Z2 & 0,803 & Valid \\
& & Z3 & 0,750 & Valid \\
& Z4 & 0,685 & Valid \\
& Z5 & 0,606 & Valid \\
\hline
\end{tabular}

Sumber: Data diolah, 2018

Berdasarkan Tabel 2, dapat disimpulkan bahwa instrumen yang digunakan dalam penelitian ini terdiri dari item-item pernyataan mengenai keterlibatan pengguna, efektivitas penggunaan SIA, dan kapabilitas personal sistem informasi adalah valid karena nilai pearson correlation positif dan besarnya di atas nilai 0,3 .

Uji ini bertujuan untuk mengukur sebuah kuesioner yang menunjukkan indikator dari variabel. Kuesioner dapat dikatakan reliabel bila jawaban seseorang terhadap pernyataan adalah konsisten atau stabil dari waktu ke waktu. Dalam penelitian ini, peneliti menggunakan pengukuran dengan cara one shot. Cara ini mengukur variabel dengan membandingkan nilai cronbach's alpha. Apabila nilai 
cronbach's alpha lebih besar dari 0,6 maka dapat dikatakan reliabel (Ghozali, 2013:48). Pada Tabel 3 disajikan hasil uji reliabilitas dari instrumen penelitian.

Tabel 3.

Hasil Uji Reliabilitas

\begin{tabular}{lcc}
\hline \multicolumn{1}{c}{ Variabel } & Cronbach's Alpha & Keterangan \\
\hline Keterlibatan Pengguna (X) & 0,799 & Reliabel \\
Efektivitas Peng. SIA (Y) & 0,762 & Reliabel \\
Kapabilitas Personal SI (Z) & 0,784 & Reliabel \\
\hline Sumber:
\end{tabular}

Sumber: Data diolah, 2018

Berdasarkan Tabel 3, ditunjukkan bahwa nilai cronbach's alpha dari masing-masing variabel memiliki nilai yang lebih besar dari 0,6 yang memiliki arti bahwa seluruh pernyataan dalam kuesioner penelitian ini reliabel dan dapat digunakan.

Pengujian regresi liner berganda dapat dilakukan setelah model dari penelitian ini memenuhi syarat yaitu lolos dari uji asumsi klasik. Syarat-syarat tersebut adalah data yang berdistribusi normal, tidak mengandung multikolinieritas dan heteroskedastisitas. Sebelum melakukan pengujian regresi linier berganda perlu dilakukan terlebih dahulu pengujian asumsi klasik. Pengujian asumsi klasik yang digunakan adalah.

Data penelitian dapat dikatakan berdistribusi normal apabila nilai Asymp. Sig (2-tailed) lebih besar daripada level of significant yang digunakan, yaitu 0,05. Pada Tabel 4.5 disajikan hasil uji normalitas penelitian.

Tabel 4.

Hasil Uji Normalitas

\begin{tabular}{cccc}
\hline No. & Persamaan & $\mathrm{N}$ & Asymp. Sig (2-tailed) \\
\hline 1. & $\mathrm{Y}=\alpha+\beta_{1} \cdot \mathrm{X}+\varepsilon$ & 52 & 0,648 \\
2. & $\mathrm{Y}=\alpha+\beta_{1} \cdot \mathrm{X}+\beta_{2} \cdot \mathrm{Z}+\beta_{3} \cdot \mathrm{X} . \mathrm{Z}+\varepsilon$ & 52 & 0,833 \\
\hline
\end{tabular}

Sumber: Data diolah, 2018

Berdasarkan tabel di atas, dapat dilihat bahwa nilai signifikansi untuk persamaan model pertama dan kedua adalah sebesar 0,648 dan 0,833. Kedua 
model tersebut memiliki nilai lebih besar dari 0,05 . Hal ini menunjukkan bahwa model regresi pada penelitian ini berdistribusi normal.

Uji ini dilakukan dengan tujuan untuk mengetahui apakah di dalam model regresi terjadi ketidaksamaan varian pada residual dari suatu pengamatan ke pengamatan. Pada Tabel 5 disajikan hasil uji heteroskedastisitas.

Tabel 5.

Hasil Uji Heteroskedastisitas

\begin{tabular}{cccc}
\hline No. & Persamaan & Variabel & Sig. \\
\hline 1. & $\mathrm{Y}=\alpha+\beta_{1} \cdot \mathrm{X}+\varepsilon$ & $\mathrm{X}$ & 0,142 \\
2. & $\mathrm{Y}=\alpha+\beta_{1} \cdot \mathrm{X}+\beta_{2} \cdot \mathrm{Z}+\beta_{3} \cdot \mathrm{X} . \mathrm{Z}+\varepsilon$ & $\mathrm{X}$ & 0,937 \\
& & $\mathrm{Z}$ & 0,712 \\
& & $\mathrm{X} . \mathrm{Z}$ & 0,648 \\
\hline
\end{tabular}

Sumber: Data diolah, 2018

Berdasarkan tabel di atas, nilai signifikansi keseluruhan lebih besar dari

0,05. Hal ini dapat disimpulkan bahwa tidak heteroskedastisitas pada model regresi dalam penelitian ini.

Analisis regresi liner sederhana dan MRA digunakan untuk mengetahui hubungan sejauh mana hubungan antara variabel bebas terhadap variabel terikat.

Tabel 6.

Hasil Analisis Regresi Linier Sederhana

\begin{tabular}{lccccr}
\hline \multirow{1}{*}{ Variabel } & \multicolumn{2}{c}{$\begin{array}{c}\text { Unstandardized } \\
\text { Coefficients }\end{array}$} & $\begin{array}{c}\text { Standardized } \\
\text { Coefficients }\end{array}$ & $\mathrm{t}$ & \multirow{2}{*}{ Sig. } \\
\cline { 2 - 4 } & $\mathrm{B}$ & Std. Error & Beta & & \\
\hline Constant & 18,575 & 2,179 & & 8,526 & 0,000 \\
Ket. Pengguna & 0,647 & 0,177 & 0,458 & 3,645 & 0,001 \\
$R$ Square & & & 0,210 & & \\
F hitung & & & 13,287 & & \\
Signifikansi F & & & 0,001 & & \\
\hline
\end{tabular}

Sumber: Data primer diolah, 2018

Berdasarkan Tabel 6 dapat disusun persamaan regresi linier sederhana sebagai berikut.

$$
\mathrm{Y}=18,575+0,647 \mathrm{X}_{1}+\varepsilon
$$


Konstanta regresi $(\alpha)$ sebesar 18,575 menunjukkan bahwa apabila nilai keterlibatan pengguna sama dengan nol, maka nilai efektivitas penggunaan sistem informasi akuntansi akan sebesar 18,575.

Konstanta regresi keterlibatan pengguna sebesar 0,647 (positif). Hal ini menunjukkan bahwa apabila keterlibatan pengguna meningkat sebesar 1 satuan, maka variabel efektivitas penggunaan sistem informasi akuntansi akan meningkat dengan asumsi variabel lain konstan.

Analisis MRA digunakan untuk mengetahui sejauh mana hubungan antara variabel bebas terhadap variabel terikat \& interaksi antara variabel bebas dan variabel pemoderasi. Berdasarkan hasil olah data dengan bantuan aplikasi SPSS, maka diperoleh hasil seperti Tabel 7 berikut.

Tabel 7.

Hasil Moderated Regression Analysis (MRA)

\begin{tabular}{|c|c|c|c|c|c|}
\hline \multirow{2}{*}{ Variabel } & \multicolumn{2}{|c|}{ Unstandardized Coefficients } & \multirow{2}{*}{$\begin{array}{c}\begin{array}{c}\text { Standardized } \\
\text { Coefficients }\end{array} \\
\text { Beta } \\
\end{array}$} & \multirow{2}{*}{$\mathrm{T}$} & \multirow{2}{*}{ Sig. } \\
\hline & $\mathrm{B}$ & Std. Error & & & \\
\hline Constant & 11,932 & 3,102 & & 3,847 & 0,000 \\
\hline Ket. Pengguna & 0,035 & 0,258 & 0,025 & 0,137 & 0,892 \\
\hline $\begin{array}{l}\text { Kap. Personal SI } \\
\text { Interaksi antara }\end{array}$ & 0,628 & 0,183 & 0,382 & 3,436 & 0,001 \\
\hline $\begin{array}{l}\text { Ket. Pengguna } \\
\text { dengan Kap. } \\
\text { Personal SI }\end{array}$ & 0,024 & 0,010 & 0,439 & 2,383 & 0,021 \\
\hline$R$ Square & & & 0,406 & & \\
\hline F hitung & & & 12,624 & & \\
\hline Signifikansi F & & & 0,000 & & \\
\hline
\end{tabular}

Berdasarkan Tabel 7 dapat disusun persamaan regresi sebagai berikut.

$$
Y=11,932+0,035 X+0,628 Z+0,024 X . Z+\varepsilon
$$

Konstanta regresi $(\alpha)$ sebesar 11,932 menunjukkan bahwa apabila nilai keterlibatan pengguna dan kapabilitas personal sistem informasi sama dengan nol, 
maka nilai efektivitas penggunaan sistem informasi akuntansi akan sebesar 11,932 satuan.

Koefisien regresi keterlibatan pengguna $\left(\beta_{1}\right)$ sebesar 0,035 (positif). Hal ini menunjukkan bahwa apabila keterlibatan pengguna meningkat sebesar 1 satuan, maka variabel efektivitas penggunaan sistem informasi akuntansi akan meningkat dengan asumsi variabel lain konstan.

Koefisien regresi kapabilitas personal sistem informasi $\left(\beta_{2}\right)$ sebesar 0,628 (positif). Hal ini menunjukkan bahwa apabila kapabilitas personal sistem informasi meningkat sebesar 1 satuan, maka variabel efektivitas penggunaan sistem informasi akuntansi akan meningkat dengan asumsi variabel lain konstan.

Koefisien regresi interaksi antara keterlibatan pengguna dengan kapabilitas personal sistem informasi $\left(\beta_{3}\right)$ sebesar 0,024 (positif). Hal ini menunjukkan bahwa apabila hubungan antara keterlibatan pengguna dengan kapabilitas personal sistem informasi meningkat sebesar 1 satuan, maka variabel efektivitas penggunaan sistem informasi memiliki kecenderungan akan meningkat dengan asumsi variabel lain konstan.

Nilai $\mathrm{R}^{2}$ dari hasil regresi moderasi digunakan untuk mengetahui seberapa besar pengaruh variabel bebas, variabel moderasi dan interaksi antara variabel moderasi dan variabel bebas terhadap variabel terikat. Berdasarkan Tabel 7, nilai $\mathrm{R}^{2}$ sebesar 0,406 . Hal ini berarti sebesar $40,6 \%$ variasi efektivitas penggunaan sistem informasi akuntansi dipengaruhi oleh keterlibatan pengguna, kapabilitas personal sistem informasi, interaksi antara keterlibatan pengguna dan kapabilitas 
personal sistem informasi. Sisanya yaitu sebesar 59,4\% dipengaruhi oleh faktor lain di luar model penelitian.

Berdasarkan Tabel 7, nilai signifikansi $\mathrm{F}$ atau dari sebesar 0,000 yang lebih kecil dari nilai $\alpha=0,05$. Hal ini menunjukkan bahwa model regresi moderasi layak untuk digunakan sebagai alat analisis untuk menguji pengaruh variabel bebas pada variabel terikat, dan interaksi hubungan variabel bebas dengan variabel pemoderasi.

Nilai signifikansi t sebesar 0,892 dimana nilai tersebut lebih besar dari 0,05. Hal ini menunjukkan bahwa keterlibatan pengguna tidak berpengaruh pada efektivitas penggunaan SIA.

Nilai signifikansi t sebesar 0,021 dimana nilai tersebut lebih kecil dari 0,05 sehingga $\mathrm{H}_{1}$ diterima. Hal ini menunjukkan bahwa kapabilitas personal sistem informasi memoderasi pengaruh keterlibatan pengguna pada efektivitas penggunaan SIA.

Berdasarkan hasil uji regresi linier sederhana, nilai signifikansi t sebesar 0,001 dimana nilai tersebut lebih kecil dari 0,05 dan $\beta$ sebesar 0,647 (positif). Dari hasil tersebut dapat dinyatakan bahwa keterlibatan pengguna berpengaruh pada efektivitas penggunaan sistem informasi akuntansi. Hal ini berarti keterlibatan pengguna sistem dalam divisi TIA pada PT. Bank Pemangunan Daerah Bali mampu meningkatkan efektivitas penggunaan sistem informasi akuntansi.

Hal ini sejalan dengan teori TAM yang menyatakan bahwa reaksi dan persepsi dari pengguna sistem akan mempengaruhi sikapnya dalam penerimaan terhadap sistem tersebut. Faktor yang dapat mempengaruhinya adalah persepsi 
pengguna terhadap kemanfaatan dan kemudahan penggunaan sistem. Hal yang terjadi pada pegawai divisi TIA pada PT. Bank Pembangunan Daerah Bali yaitu timbulnya persepsi yang positif mengenai sistem tersebut. Keterlibatan pengguna pada divisi TIA di PT. Bank Pembangunan Daerah Bali mampu meningkatkan efektivitas penggunaan sistem informasi akuntansi.

Hasil penelitian ini sejalan dengan penelitian yang dilakukan oleh Setianingsih (1998), Jin (2002), dan (Ismail, 2009) yang menyatakan bahwa keterlibatan pengguna sistem yang intens akan meningkatkan kinerja sistem informasi akuntansi dikarenakan adanya hubungan yang positif antara keterlibatan pengguna dalan proses pengembangan sistem dalam kinerja sistem informasi akuntansi.

Hasil pengujian analisis regresi moderasi (MRA), nilai signifikansi t sebesar 0,021 dimana nilai tersebut lebih kecil dari 0,05 dan $\beta_{3}$ sebesar 0,024 (positif). Dari hasil tersebut dapat dinyatakan bahwa variabel kapabilitas personal sistem informasi memperkuat hubungan antara keterlibatan pengguna dengan efektivitas penggunaan sistem informasi akuntansi. Kapabilitas personal terbukti mampu meningkatkan partisipasi pengguna sistem informasi yang berimbas pada efektifnya penggunaan sistem informasi akuntansi. Kemampuan pengguna dalam mengoperasikan suatu sistem sangat dibutuhkan. Terkadang terjadi kesalahan ataupun kegagalan sistem dalam memberikan informasi yang dibutuhkan dikarenakan kurangnya kemampuan dan pengetahuan seputar sistem yang dimiliki oleh pengguna. Hal ini dapat berpengaruh pada pengambilan keputusan suatu perusahaan. Sehingga kapabilitas personal sistem informasi memoderasi pengaruh 
keterlibatan penggunaa pada efektivitas penggunaan sistem informasi akuntansi pada PT. Bank Pembangunan Daerah Bali. Kapabilitas personal umumnya diperoleh dari pengetahuan dan pengalaman seseorang dalam menjalankan suatu sistem.

Faktor pengalaman berkaitan erat dengan salah satu faktor dari teori TAM, yaitu faktor kemudahan yang dirasa dalam penggunaan sistem (ease of use). Menurut (Wijaya, 2006), kemudahan yang dirasa dalam menggunakan sistem dipengaruhi oleh beberapa faktor, diantaranya. Faktor pertama berfokus pada sistem itu sendiri, misalnya pengalaman pengguna terhadap pengguna sistem yang sejenis. Pengalaman baik pengguna akan sistem yang sejenis akan mempengaruhi persepsi pengguna terhadap suatu sistem. Faktor kedua adalah reputasi akan sistem tersebut yang diperoleh oleh pengguna. Reputasi yang baik yang didengar oleh pengguna akan mendorong keyakinan pengguna akan kemudahan penggunaan sistem tersebut, demikian pula sebaliknya. Faktor ketiga yang mempengaruhi persepsi pengguna terhadap kemudahan penggunaan sistem adalah tersedianya mekanisme support yang handal.

Kemudahan (ease) bermakna tanpa kesulitan atau terbebaskan dari kesulitan atau tidak perlu berusaha keras. Dengan demikian, persepsi mengenai kemudahan menggunakan ini merujuk pada keyakinan individu bahwa sistem yang akan digunakan tidak merepotkan atau tidak membutuhkan usaha yang besar, pada saat digunakan.

Kapabilitas personal sistem informasi sangat diperlukan dalam mengerjakan suatu tugas. Kapabilitas seseorang umumnya diperoleh dari 
pendidikan dan pengalamannya yang nantinya akan meningkatkan kepuasan dalam menggunakan sistem informasi akuntansi dan akan terus menggunakannya dalam membantu menyelesaikan pekerjaannya. Kapabilitas personal dalam mengoperasikan suatu sistem informasi sangat diperlukan untuk mengurangi kesalahan maupun kegagalan pengoperasian sistem. Keberhasilan dalam pengembangan sistem informasi sangatlah bergantung pada kesesuaian antara analisis sistem dan pemakai sistem (Neely \& Cook, 2011).

Hasil penelitian ini sejalan dengan penelitian yang dilakukan oleh Irma (2015), dan Tedy, (2015) yang menyatakan bahwa kemampuan teknik personal berpengaruh terhadap kinerja sistem informasi akuntansi pada tempat yang berbeda, hal tersebut mendapat hasil yang sama pada penelitian (Aditya \& Widhiyani, 2018) yang menyatakan terdapat pengaruh positif antara kemampuan teknik personal terhadap efektivitas sistem informasi akuntansi. Kapabiltas personal sistem informasi yang baik akan menunjukkan sejauh mana kualitas pribadi seseorang dalam menguasai teknik pengelolaan sistem informasi yang dikembangkan. Demi terciptanya informasi yang akurat, karyawan dituntut untuk menguasai penggunaan sistem informasi agar memudahkan dalam pelaksanaannya.

Penelitian ini menghasilkan bukti empiris bahwa keterlibatan pengguna berpengaruh pada efektivitas penggunaan sistem informasi akuntansi. Hasil penelitian ini sejalan dengan teori TAM yang menyatakan bahwa reaksi dan persepsi dari pengguna sistem akan mempengaruhi sikapnya dalam penerimaan terhadap sistem tersebut. Keterlibatan pengguna mampu meningkatkan efektivitas 
penggunaan sistem informasi akuntansi pada pegawai divisi TIA PT. Bank Pembangunan Daerah Bali. Keterlibatan pengguna sistem yang intens akan meningkatkan kinerja sistem informasi akuntansi.

Penelitian ini juga menghasilkan bukti empiris bahwa kapabilitas personal sistem informasi memoderasi pengaruh keterlibatan pengguna pada efektivitas penggunaan sistem informasi akuntansi. Kapabilitas personal terbukti mampu meningkatkan partisipasi pengguna sistem informasi yang berimbas pada efektifnya penggunaan sistem informasi akuntansi. Kapabilitas personal umumnya diperoleh dari pengetahuan dan pengalaman seseorang dalam menjalankan suatu sistem. Faktor pengalaman berkaitan erat dengan salah satu faktor dari teori TAM, yaitu faktor kemudahan yang dirasa dalam penggunaan sistem (ease of use). Kapabilitas pengguna sistem sangat diperlukan dalam mengerjakan suatu tugas. Kapabilitas seseorang umumnya diperoleh dari pendidikan dan pengalamannya yang nantinya akan meningkatkan kepuasan dalam menggunakan suatu sistem dan akan terus menggunakannya dalam membantu menyelesaikan pekerjaannya.

Hasil penelitian ini dapat memberikan dampak positif bagi seluruh pihak, khususnya pada PT. Bank Pembangunan Daerah Bali dalam meningkatkan efektivitas penggunaan sistem informasi akuntansi. Penelitian ini juga menjelaskan bahwa perkembangan teknologi informasi telah berkembang pesat, dengan memanfaatkan teknologi informasi sehingga tercapainya solusi yang akan mempermudah Bank Pembangunan Daerah Bali maupun perusahaan lain yang bergerak di sektor perbankan dalam menggunakan sistem yang telah terintegrasi 
dengan komputer untuk mengerjakan tugas dalam rangka meningkatkan kesejahteraan, baik bagi masyarakat maupun lembaga yang terkait.

\section{SIMPULAN}

Berdasarkan hasil penelitian yang telah dilakukan, dapat disimpulkan bahwa keterlibatan pengguna tidak berpengaruh pada efektivitas penggunaan sistem informasi akuntansi. Namun, keterlibatan pengguna yang ditunjang oleh kapabilitas personal sistem informasi mampu meningkatkan efektivitas penggunaan sistem informasi akuntansi. Kapabilitas merupakan aset vital yang wajib dimiliki oleh setiap partisipan dari suatu sistem informasi dalam meningkatkan kualitas kinerja.

\section{REFERENSI}

Aditya, A. A. N. Y. K., \& Widhiyani, N. L. S. (2018). Pengaruh Kecanggihan Teknologi Pada Efektivitas Sia dengan Dukungan Manajemen Puncak, dan Kemampuan Teknik Personal Sebagai Pemoderasi Fakultas Ekonomi dan Bisnis Universitas Udayana ( Unud ), Bali , Indonesia Fakul. E-Jurnal Akuntansi Universitas Udayana, 23(1), 705-733.

Almilia, L. S., \& Briliantien, I. (2007). Faktor-faktor yang Mempengaruhi Kinerja Sistem Informasi Akuntansi pada Bank Umum Pemerintah di Wilayah Surabaya dan Sidoarjo. Jurnal STIE Perbanas Surabaya, (February). https://doi.org/10.1080/02699931.2012.691087

Ariyanto, D. (2007). Pengaruh Efektivitas Penggunaan dan Kepercayaan Teknologi Sistem Informasi Terhadap Kinerja Individual. Jurnal Akuntansi Dan Bisnis, 3(1), 23.

Damana, A. W. A. (2016). Pengaruh Keterlibatan Pemakai, Pelatihan, Ukuran Organisasi Dan Keahlian Pemakai Terhadap Kinerja Sistem Informasi Akuntansi. E-Jurnal Akuntansi Universitas Udayana., 14, 1-29.

Davis, F. D. (1986). A technology acceptance model for empirically testing new end-user information systems: theory and results. PhD Dissertation, (January 
1985), 291. https://doi.org/oclc/56932490

Davis, F. D., Bagozzi, R. P., \& Warshaw, P. R. (1989). User Acceptance of Computer Technology: A Comparison of Two Theoretical Models. Management Science, 35(8), 982-1003. https://doi.org/10.1287/mnsc.35.8.982

Dehghanzade, H., Moradi, M. A., \& Raghibi, M. (2011). A Survey of Human Factors' Impacts on the Effectiveness of Accounting Information Systems. International Journal of Business Administration, 2(4), 166-174. https://doi.org/10.5430/ijba.v2n4p166

Grande, E. U., Estébanez, R. P., \& Colomina, C. M. (2011). Cluster analysis for anomaly detection in accounting. The International Journal of Digital Accounting Research, 11(June 2010), 69-84. https://doi.org/10.4192/15778517-v11

Handayani, R. (2010). Analisis Faktor-Faktor yang Menentukan Fektivitas Sistem Informasi pada Organisasi Sektor Publik. Jurnal Akuntansi Dan Keuangan, 12, 26-40. https://doi.org/10.1182/blood-2010-06-291930

Indra, I. K., \& Suaryana, I. G. N. A. (2018). Pengaruh Efektivitas Sistem Informasi Akuntansi terhadap Kinerja Individual dengan Insentif sebagai Variabel Pemoderasi pada LPD. E-Jurnal Akuntansi Universitas Udayana, 23(2), 891-897.

Irma, D. P. (2015). Pengaruh Kemampuan Teknik Personal, Program Pelatihan, dan Pendidikan Pemakai, Insentif dan Partisipasi Manajemen pada Kinerja Penerapan Sistem Informasi Akuntansi. Skripsi Universitas Udayana, 3, 582-592.

Ismail, N. A. (2009). Factors Influencing AIS Effectiveness Among Manufacturing SMEs: Evidence From Malaysia. The Electronic Journal of Information Systems in Developing Countries, 38(1), 1-19. https://doi.org/10.1002/j.1681-4835.2009.tb00273.x

Jin, T. F. (2002). Analisis Faktor-Faktor yang Mempengaruhi Pemanfaatan Teknologi Informasi dan Pengaruh Pemanfaatan Teknologi Informasi terhadap Kinerja Akuntan Publik. Universitas Gadjah Mada.

Kharisma, M. D., \& Dharmadiaksa, I. B. (2015). Pengaruh keterlibatan pengguna dan ukuran organisasi pada efektivitas penggunaan sistem informasi akuntansi. E-Jurnal Akuntansi Universitas Udayana., 3, 867-881.

Komara, A. (2015). Canadian Journal of Learning and Technology. Jurnal Manajemen, Akuntansi \& Sistem Informasi, 6(2), 143-160. Retrieved from 
http://agus.byethost13.com/books/2012sia1/2012_mujilan_sia.pdf?i=1

Larasdiputra, G. D., \& Suryanawa, I. K. (2014). Penerapan Sistem Informasi Akuntansi pada Bank Perkreditan Rakyat Sari Jaya Sedana Klungkung. EJurnal Akuntansi Universitas Udayana, 7(3), 791-805. https://doi.org/10.1109/TNS.1983.4333156

Neely, M. P., \& Cook, J. S. (2011). Fifteen Years of Data and Information Quality Literature: Developing a Research Agenda for Accounting. Journal of Information Systems, 25(1), 79-108. https://doi.org/10.2308/jis.2011.25.1.79

Novita, H. (2011). Efektifitas Sistem Informasi Akuntansi Dampaknya terhadap Kinerja Karyawan pada PT Dwi Daya Sentra Prakasa (Persero), 2011.

Rahmawati, D. (2008). Analisis Faktor-Faktor Yang Berpengaruh Terhadap Pemanfaatan Teknologi Informasi. Jurnal Ekonomi \& Pendidikan. https://doi.org/DOI: 10.1016/j.envsoft.2006.05.024

Rusdi, D., \& Megawati, N. (2014). Analisis Faktor-Faktor yang Mempengaruhi Kinerja Sistem Informasi Akuntansi (SIA). Jurnal Paradigma, 12(1986), 93112.

Setianingsih, Sunarti, Indriantoro, \& Nur. (1998). Pengaruh Dukungan Manajemen Puncak dan Komunikasi Pemakai terhadap Hubungan Partisipasi dan Kepuasan Pemakai dalam Pengembangan Sistem Informasi. Jurnal Riset Akuntansi Indonesia, 1(2), 192-207.

Tedy, A. P. Y. (2015). Pengaruh Partisipasi Pengguna Sistem Informasi Dan Kemampuan Pengguna Sistem Informasi Terhadap Kinerja Sistem Informasi Akuntansi. E-Proceeding of Manajemen, 2(3), 3131.

Widjajanto, N. (2001). Sistem Informasi Akuntansi. Jakarta: Erlangga.

Wijaya, S. (2006). Kajian Teoritis Technology Acceptance Model sebagai Model Pendekatan untuk Menentukan Strategi Mendorong Kemauan Pengguna dalam Menggunakan Teknologi Informasi dan Komunikasi. Prosiding Konferensi Nasional Sistem Informasi. Yogyakarta.

Wilayanti, N. W., \& Dharmadiaksa, I. B. (2016). Keterlibatan dan Kemampuan Teknik Personal pada Efektivitas Penggunaan Sistem Informasi Akuntansi. E-Jurnal Akuntansi Universitas Udayana, 15(2), 1310-1337.

Zare, I. (2012). Study of Effect of Accounting Information Systems and Softwares on Qualitative Features of Accounting Information. International Journal of Management Sciences and Business Research, 1(4), 1-12. 